\title{
Polyomavirus BK replication in renal transplant recipients: combined monitoring of viremia and VPI mRNA in urine
}

Sara Astegiano', Maria Elena Terlizzi', Samantha Mantovani', Maria Messina², Francesca Sidoti', Giuseppe P. Segoloni' ${ }^{2}$ Rossana Cavallo', Cristina Costa', Massimiliano Bergallo'

I Dipartimento di Sanità Pubblica e Microbiologia, Laboratorio di Virologia, Università di Torino and

2 Dipartimento di Medicina Interna, Unità Trapianto Rene, Ospedale Molinette, Torino, Italy

Key words: BK virus, kidney transplantation, PCR

Monitoraggio della replicazione del polyomavirus BK nel trapiantato renale mediante valutazione combinata del DNA su siero e del VPI mRNA su urine

\section{SUMMARY}

Introduction. Human polyomavirus BK (BKV) is worldwide distributed, with a seroprevalence rate of $70-90 \%$ in the adults. Following primary infection, BK remains latent in the renourinary tract as the epidemiologically most relevant latency site, and in B cell, brain, spleen and probably other tissues. Reactivation may occur in both immunocompetent subjects and immunocompromised patients. In renal transplantation, in the context of intense immunosuppression, viral replication may determine BKV-associated nephropathy (BKVAN) with interstitial nephritis and/or ureteral stenosis in $1-10 \%$ of the patients and leading to graft failure and return to haemodialysis in 30 to $80 \%$ of the cases (5).

Screening of BKV replication represents the basic strategy to predict early the onset of BKVAN and may allow for earlier intervention with reduced allograft loss $(3,4)$.

Nowadays, replication of BKV is monitored by quantification of BKV-DNA in serum and urine (2).

The aim of this study was to evaluated the role of BKVVPI mRNA in urine as a marker of viral replication in renal transplant recipients.

\section{METHODS}

531 kidney transplant recipients were studied. BKV-DNA was evaluated using a commercial Real Time PCR Kit (BKV Q-PCR Alert Kit, Nanogen Advanced Diagnostics, Milan, Italy) and VP1 mRNA was quantified by a standardized home made RT-Real Time PCR (1) and then normalized on the number of urinary cells, in order to define VP1 mRNA as a marker of active replication of the virus.

\section{RESULTS}

Results are summarized in Table 1. Briefly, 45/531 (8.5\%) and 68/531 (12.8\%) patients were positive to BKV-DNA on serum and on urine, respectively. A diagnosis of BKVAN was placed in two patients. Viral replication, based on VP1 mRNA, was present in 11/531 (2.1\%) patients, in particular
5/102 (4.9\%) in the first year post-transplantation; two of them $(40 \%)$ with BKVAN. VP1 mRNA was observed in all cases, except 5, associated with viremia and in all cases with viruria. No significant difference was found between VP1 mRNA in the two patients with nephropathy and those without. Considering receiving operating characteristics, the VP1 mRNA was not higher than viremia, despite combined measurements between viremia (cut-off 16000 copies $/ \mathrm{ml}$ ) and the VP1 mRNA (cut-off $>10000$ copie/10 $10^{3}$ cells).

\section{CONCLUSIONS}

VP1 mRNA could be a complementary test together with viremia and viruria for the monitoring of BKV replication, although further studies will be needed in order to define a possible role in the therapeutic management of kidney transplantation.

Table I. Results on the comparison between BKV viremia and VPI mRNA

\begin{tabular}{|c|c|c|c|}
\hline & Samples $N=1082$ & Patients $\mathbf{N}=53 \mathrm{I}$ & Patients with BKVAN N=2 \\
\hline 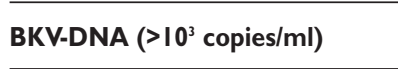 & $84(7.8 \%)$ & $\begin{array}{c}45(8.5 \%) \\
>1.6 \times 10^{4} \text { copies } / \mathrm{ml} \text { in II cases }(2.1 \%)\end{array}$ & $>1.6 \times 10^{4}$ copies $/ \mathrm{ml}$ in both cases \\
\hline VPI mRNA ( $>10^{3}$ copies $/ 10^{3}$ cells) & $26(2.4 \%)$ & $\begin{array}{c}\text { II (2.1\%) mean: } 95681.5 \text { copies/ } 103 \text { cells } \\
5(0.9 \%)\end{array}$ & $\begin{array}{c}>10^{5} \text { copies } / 10^{3} \text { cells } \\
>105 \text { copies } / 103 \text { cells in both cases }\end{array}$ \\
\hline
\end{tabular}

\section{BIBLIOGRAFIA}

1. Bergallo M, Astegiano S, Sidoti F, et al. Real-Time RT-PCR assay for the quantitation of polyomavirus BK VP1 mRNA levels in urine. Mol Biotechnol 2010 Jan 27. (Epub ahead of print)

2. Costa C, Bergallo M, Astegiano S, et al. Monitoring of BK virus replication in the first year following renal transplantation. Nephrol Dial Transplant 2008; 23: 3333-6.
3. Hariharan S. BK virus nephritis after renal transplantation. Kidney Int 2006; 69: 655-662.

4. Hirsch HH, Brennan DC, Drachenberg CB, et al. Polyomavirus associated nephropathy in renal transplantation: interdisciplinary analyses and recommendations. Transplantation 2005; 79: 1277-86.

5. Nickeleit V, Singh HK, Mihatsch MJ. Polyomavirus nephropathy: morphology, pathophysiology, and clinical management. Curr Opin Nephrol Hypertens 2003; 12: 599-605.

\section{Corresponding author: Cristina Costa}

Dept. of Public Health and Microbiology, Virology Unit

I0I26 Turin, Italy - Via Santena 9 - Phone: + 39(I I)6705630 - Fax: +39(I I)6705648

E-mail: cristina.costa@unito.it 